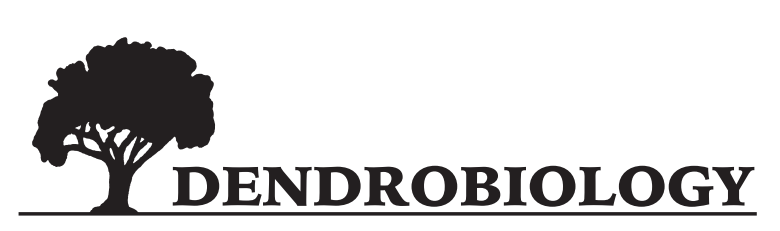

2018, vol. 79, 141-155

http://dx.doi.org/10.12657/denbio.079.013

\author{
Igor Štefančík, Zdeněk Vacek*, Ram P. Sharma, Stanislav Vacek, \\ Michaela Rösslová
}

\title{
Effect of thinning regimes on growth and development of crop trees in Fagus sylvatica stands of Central Europe over fifty years
}

\author{
Received: 2 July 2017; Accepted: 23 April 2018
}

\begin{abstract}
Crop trees are the main component of the qualitative and value production of forest stands. Therefore, stand density of crop trees is one of the most important information items for comparing different management strategies in forestry. Although the number of crop trees per hectare and their productivity are influenced by various factors, thinning can be one of the most important among them. This article aims to compare the growth and development of crop trees in European beech (Fagus sylvatica L.) stands, which have been managed by three different thinning types over 50 years: heavy thinning from below, free-crown thinning and without thinning (or control). The measurements and assessments of crop trees were made using three essential criteria (best stem quality, diameter and height dimensions, regularity of spacing) every four or five years during 50 years. More than 9,000 assessments of crop trees with stand ages ranging from 30 to 105 years on 23 sample plots across Slovakia were analyzed. The highest number of crop trees was reached in a stand where free-crown thinning was applied. The proportion of crop trees on the subplots managed by crown thinning was $61 \%$ of the stand basal area and $66 \%$ of the merchantable volume at stand age of 100 years. However, much lower proportions of crop trees were found on the subplots managed by thinning from below $(32 \%$ and $32 \%)$ and control $(20 \%$ and $21 \%)$, respectively. The subplots, where freecrown thinning was applied, showed significantly higher values of other quantitative characteristics (e.g., diameter increment, height-diameter ratio, crown width) than those on the subplots managed with the other two thinning types (low thinning and control). Based on the results from a systematic investigation after 50 years, free-crown thinning is recommended for selective thinning in beech forests.
\end{abstract}

Keywords: European beech, crown thinning, low thinning, basal area proportion, stand skeleton, stand stability

Addresses: I. Štefančík, Z. Vacek, Ram P. Sharma, S. Vacek, M. Rösslová, Czech University of Life Sciences Prague, Faculty of Forestry and Wood Sciences and Faculty of Environmental Sciences, Kamýcká 129, 16521 Prague 6 - Suchdol, Czech Republic, e-mail: vacekz@fld.czu.cz.cz

I. Štefančík, National Forest Centre, Forest Research Institute, T. G. Masaryka 22, 96092 Zvolen, Slovak Republic 


\section{Introduction}

The growth and development of beech stands are significantly influenced by various factors, such as site and environmental factors (Pichler et al., 2009; Vacek \& Hejcman, 2012; Bošela et al., 2016; Vacek et al., 2017a); stand structure and competition (Jullien et al., 2013; Vacek et al., 2014a, 2015a, 2015b; Dassot et al., 2015; Bulušek et al., 2016), genetic characteristics including species provenance (Hansen et al., 2003; Gömöry \& Paule, 2011; Gömöry et al., 2013), and management intervention (Barna et al., 2010; Ratnam et al., 2014; Westergren et al., 2015). Natural or anthropogenic disturbances (Zeibig et al., 2005; Fichtner et al., 2012; Vacek et al., 2014b; Králíček et al., 2017) and masting behavior of the species also influence the growth and development of the stands (Piovesan \& Adams, 2001; Drobyshev et al., 2010; Vacek et al., 2017b). However, among the above-mentioned factors, management, thinning or any type of selection cutting could have a substantial influence on stand growth and development (Fürst et al., 2007; Utzschig, 2013; van der Maaten, 2013; Štefančík, 2015).

Little attention was paid to the quantitative production of beech stands in the past (Kennel, 1972; Polge, 1981; LeGoff \& Ottorini, 1993; Dhôte, 1997), but in recent years, much more attention has been paid to quality and value production(Štefančík, 2015). For this reason, various thinning methods have been developed and evaluated for their potential contributions to the increased quality and value of beech timber production (Štefančík, 1984, 2015; Altherr, 1981; Abetz \& Ohnemus, 1999; Armand \& Ningre, 2003).

There have been positive effects of long-term thinning on the growth and development of beech stands (Utzschig \& Küsters, 2003; Pretzsch et al., 2008) and their timber quality (Ekö et al., 1995; Štefančík, 2015). In addition, thinning in general, but selective thinning in particular, has had a positive effect on the quality of beech timber (Cameron, 2002; Boncina et al., 2007; Poljanec \& Kadunc, 2013). Thinning is always aimed at supporting the promising crop trees (target crops), which is also useful in terms of the quality and value production (Skovsgaard et al., 2006; Hein et al., 2007). Crop trees are predominantly located in the upper layer of a stand, which correspond to the management, technical and economic objectives. Crop trees are selected at young stages (20-30 years of age) according to the promising quality characteristics of stem and crown, other dimensional requirements and appropriate spacing according to tree species, age, and site quality (Štefančík, 2012). In terms of timber quality, more promising results have been shown through the application of crown thinning compared to thinning from below (Štefančík \& Bošela, 2014). This may be a reason why an early and heavy crown thinning is often recommended for beech stands (Spellmann \& Nagel, 1996; Guericke, 2002).

In the Slovak Republic, a special method of crown thinning was applied for thinning of beech stands toward the end of 1950s (Štefančík, 1984). Actually, it was a free-crown thinning, which was reported as the most suitable for thinning of monospecific beech stands in Slovakia. This method mainly focused on individual thinning and/or cultivation of the desired number of crop trees. Crop trees of any stand represent "storage" of the best quality trees, and therefore they are considered as a "stand skeleton", which is assumed to ensure the favorable static stability of a stand. Moreover, crop trees are also the main component of quantitative production in stands (Štefančík, 1984). The cultivation of crop trees depends on various factors, such as site quality, but especially on the thinning operation that can be considered as a main influencing factor at the time of crop tree selection (Poljanec \& Kadunc, 2013; Remeš et al., 2015).

Various approaches for selecting crop trees in beech stands are practiced, which take into account certain criteria (stem quality, dimension, spacing - Štefančík, 1984), norms (tree density according to basal area, height and breast diameter - Altherr, 1981; Abetz \& Ohnemus, 1999), sivicultural system (types and level of thinning- Armand \& Ningre, 2003). Stand age of about 40 year was found to be an appropriate selection age for the first thinning and securing the optimal crop trees (Spellmann \& Nagel, 1996; Guericke, 2002). However, Lüpke (1986) has recommended that the first thinning including crop tree selection in the monospecific beech stands should be done at the age of 45 to 55 years. Selection and subsequent cultivation of these trees at older ages resulted in a lower number of the desired crop trees at a given rotation age (Štefančík, 2013).

According to the results from many studies (Oswald, 1981; Foerster, 1993; Boncina et al., 2007; Hein et al., 2007), a primary aim of reducing the stand density through thinning is not only to promote the best (crop) trees in a stand for a high quality timber production, but also to improve the static stability of stands against wind, snow and icing (Nykänen et al., 1997; Jiao-jun et al., 2003; Sharma et al., 2016b). It is necessary to support stand stability by application of crown thinning with positive selection (selection aimed at supporting/releasing the best trees in a stand), where, as a rule, trees with the largest diameter and the highest vitality are released, ensuring free growth and development of the crowns (Štefančík, 1984). This may be possible through selective cultivation of tree quality, i.e., promising crop trees, which consists of selection and marking of the required number of trees in a stand followed by the release of their crowns through positive interventions (Hein et al., 2007). Different numbers of crop trees 
per hectare are often recommended. For example, two-fold numbers of crop trees are desirable in the promising tree method compared to crop tree method such as reserve, because during the next development (aged 50-60 years) crop trees are determined from these promising trees (Štefančík, 2012). These numbers form a stand skeleton that could ensure the favorable static stability of a stand where its average slenderness coefficient would be less than 0.8 (Rymer-Dudzińska \& Tomusiak, 2000). Furthermore, crown release of crop trees could have a positive effect on trees, mainly on diameter growth (Leak \& Solomon, 1997; Sharma et al., 2016a, 2017a, 2017b).

Even though various studies on thinning of beech stands have been carried out to date, it is still questionable whether different management interventions could significantly influence the number of crop trees in beech stands as compared to stands without any management intervention. Furthermore, data on the growth and development of longterm crop trees in relation to certain thinning methods are rarely available. Therefore, in this study, we focused on analysis of the growth and development of crop trees in monospecific beech stands at seven sites across Slovakia, which were systematically managed through the application of two different thinning methods for over 50 years. The objective of this study was to evaluate the long-term development of beech stands based on data from crop trees managed by two different thinning methods, such as free-crown thinning according to Štefančík (1984), heavy thinning from below ( $\mathrm{C}$ grade according to the German forest research institutes from 1902), and without thinning. We tested the hypothesis whether beech stands managed by the application of different thinning methods would produce different numbers of crop trees and basic quantitative characteristics such as diameter increment, height, height-diameter ratio, crown width, stand basal area, and stand volume production. In addition to this, we also tested the hypothesis whether the relationships of tree- and stand-level variables of interest could be modelled using mathematical functions for each thinning type.

\section{Materials and methods}

\section{Study site}

This study was conducted on beech stands in the Western Carpathian Mountains of the Central and Eastern part of the Slovak Republic (Fig. 1). Twenty-three long-term research subplots (LTRPs) at seven sites across Slovakia were established between 1959 and 1969 (Štefančík, 1972, 2015). At the time of LTRPs establishment, stands were classified by growth phases as smaller to larger pole-staged stands, but at present, their stand age varies from 83 to 105 years. The LTRPs represented the even-aged homogeneous beech forests in Slovakia. The stands originated from natural regeneration, and various thinning and other silvicultural operations were applied. No major thinning operation was carried out in these stands until the research began. However, a few light thinning operations were applied only to the suppressed trees, which are also known as wandering-selective felling (Štefančík, 1972, 1973). The study sites are located in a sub-mountain vegetation belt, with elevation ranging from 250 to $700 \mathrm{~m}$ (Table 1). The study sites comprise monospecific beech stands characterized by Fagetum pauper, Fagetum typicum, Fageto-abietinum and Querceto-Fagetum forest types.

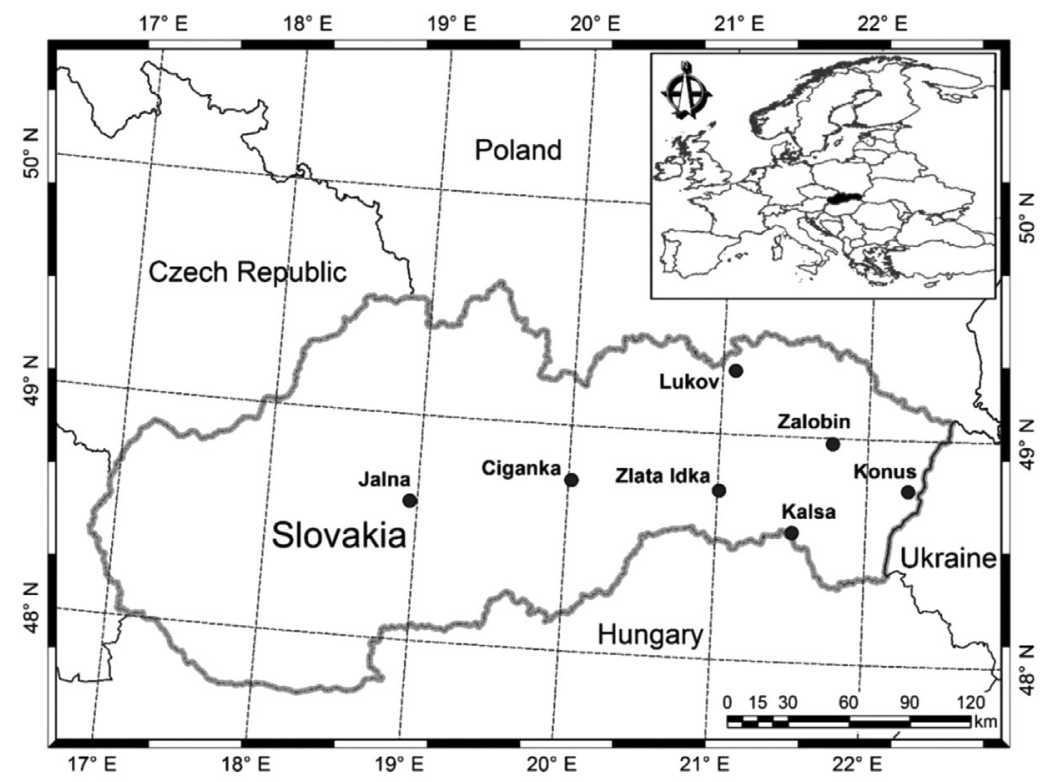

Fig. 1. Location of seven sites of thinning experiments in monospecific beech stands 
Table 1. Site characteristics of long-term research plots in European beech stands. Subplots indicate different type of thinning [0 - control plot (no thinning); 1 - heavy thinning from below (C-grade, following the principles of German Forest Research Institute, 1902); 2 - free-crown thinning according to Štefančík (1984) principles, thinning interval of 4 or 5 years]

\begin{tabular}{|c|c|c|c|c|c|c|c|c|c|}
\hline \multirow{2}{*}{$\begin{array}{l}\text { Long-term research } \\
\text { plot/subplot }\end{array}$} & \multirow{2}{*}{$\begin{array}{c}\text { Number of } \\
\text { measurements }\end{array}$} & \multirow{2}{*}{$\begin{array}{c}\text { First-last } \\
\text { measurement }\end{array}$} & \multirow{2}{*}{$\begin{array}{c}\text { Age span } \\
\text { (years) }\end{array}$} & \multicolumn{2}{|c|}{$\begin{array}{l}\text { Geographic } \\
\text { position }\end{array}$} & \multirow{2}{*}{$\begin{array}{l}\text { Altitude } \\
\text { (m) }\end{array}$} & \multirow{2}{*}{$\begin{array}{l}\text { Mean tem- } \\
\text { per. }\left({ }^{\circ} \mathrm{C}\right)\end{array}$} & \multirow{2}{*}{$\begin{array}{l}\text { Mean pre- } \\
\text { cipit. (mm) }\end{array}$} & \multirow[t]{2}{*}{ Soil unit } \\
\hline & & & & $\mathrm{N}$ & $\mathrm{E}$ & & & & \\
\hline Jalna/0, 1,2 & 12 & 1959-2012 & $36-89$ & 48.55 & 18.95 & 610 & 6.2 & 800 & Eutric Cambisol \\
\hline Konus/0, 1, 2 & 12 & 1961-2014 & $30-83$ & 48.78 & 22.30 & 510 & 6.5 & 900 & Eutric Cambisol \\
\hline Kalsa/0, 1, 2 & 12 & 1961-2014 & $37-90$ & 48.58 & 21.48 & 520 & 6.0 & 790 & $\begin{array}{l}\text { Stagni-Eutric } \\
\text { Cambisol }\end{array}$ \\
\hline Zalobin/0, 1, 2 & 12 & $1962-2015$ & $39-92$ & 48.98 & 21.74 & 250 & 7.9 & 660 & $\begin{array}{l}\text { Stagni-Eutric } \\
\text { Cambisol }\end{array}$ \\
\hline Zlata Idka/0, 1, 2 & 12 & 1960-2013 & $40-93$ & 48.74 & 21.01 & 700 & 6.7 & 780 & Haplic Cambisol \\
\hline Ciganka/0, 1, 2 & 10 & 1967-2012 & $60-105$ & 48.76 & 20.09 & 560 & 5.5 & 918 & Haplic Cambisol \\
\hline & 12 & & & 49.28 & & 55 & 5. & $6 s$ & Haplic Cambisol \\
\hline Lukov/1 & 11 & $1966-2016$ & 49-94 & 49.28 & 21.10 & 550 & 5.5 & 690 & Haplic Cambisol \\
\hline
\end{tabular}

\section{Sampling and measurements}

Each LTRP comprised multiple subplots, varying from three to five (mostly three), which were arranged next to each other along a contour line, and were separated from each other by a $5 \mathrm{~m}$ wide buffer zone. The area of each subplot is 0.25 ha $(50 \times 50 \mathrm{~m})$. A $10 \mathrm{~m}$ wide transect, where height components (total height and height to crown base) of the trees were measured, was established and fixed through the center of each subplot. In addition, heights of the selected crop trees (target trees) on each subplot were measured. In the beginning of our studies all living trees with diameter at breast height $(\mathrm{DBH}) \geq 3.6 \mathrm{~cm}$ and/or trees which reached this threshold during measurements were numbered. Apart from DBH, total height, and height to crown base (HCB), crown width (CW) were also measured in crop trees at each inventory cycle during the study period. One subplot in each LTRP was left as a control subplot, where none of the management interventions was applied.

According to the classification by Kraft (1884), the attributes assessed at each inventory cycle were: social position of the trees within a stand (1 - dominant; 2 co-dominant; 3 - sub-dominant; 4 - suppressed), stem quality ( 1 - straight high quality stem without knots, with no visible external damage; 2 - average quality, stem curvature allowed only in the higher one third of the stem, low number of small knots ( 1 or 2 pieces per running meter) allowed, with no external damage (fungi, insects, necrosis); 3 - low quality stem with a high number of knots (more than 2 pieces per running meter), crown size (1 - appropriate-sized symmetrical crown; 2 - appropriate-sized asymmetrical crown; 3 - suppressed small-sized, but able to regenerate after releasing; 4 - extremely small, unable to regenerate).

The thinning types applied in the beech stands were: "low thinning" - heavy thinning from below (C-grade, following the principles defined by the German Forest Research Institute released in 1902) and "crown thinning" - free-crown thinning or thinning from above applied in 5- and 10-year's intervals (Štefančík, 1984). The main objective of free-crown thinning was to grow promising trees with the model number of crop trees at cutting age (110-130 years). The model number of crop trees should reach about 170-220 trees ha ${ }^{-1}$ with spacing around $7.5 \mathrm{~m}$ on acidic sites and 120-180 trees ha ${ }^{-1}$ with spacing 8-9 $\mathrm{m}$ on fertile sites in the monospecific beech stands (Štefančík, 1984). The principle of crown thinning lies in supporting the selected best quality trees (crop trees) by removing their potential competitors. Here, an emphasis was put not only on high quality of the stems without knots, with no visible external damage, dimensions (as large as possible diameter and height), but also on the crown shape (continuous bole axis to tree-top) and spacing (more or less regular arrangement) of crop trees (Štefančík, 1984). However, crop trees were usually dominant or co-dominant in the canopy layer (classes 1 or 2 according to the Kraft' classification (Kraft 1884). These trees on each subplot were selected on the first measurement and reassessed based on the above-mentioned criteria at every 4th (second and third interventions) or 5th year. Only those trees competing with the crop trees were marked and felled in each measurement year. In total, 10 to 12 measurements and assessments of crop trees were performed up to 2017.

\section{Data analysis}

Some subplots underwent crown thinning at 5 -year intervals and some subplots at 10-year intervals. For statistical analysis, all subplots, for example, those managed with crown thinning, were grouped into a single thinning type, i.e., crown thinning. Height-diameter models for each inventory cycle on each subplot during the study period were developed using height and DBH measurements in order to 
predict the missing measurements for all other trees for which heights were not measured. The top stand height (hereafter termed as dominant height: HDOM, m) was calculated from the height measurements of the hundred largest DBH trees ha ${ }^{-1}$. Also, considering the principle that crop trees would create an important stand skeleton of a forest and also these trees could play a crucial role in order to ensure the appropriate static stability against abiotic disturbances, mainly wind, we analyzed the slenderness quotient (HDR - ratio of HDOM to DBH of dominant trees, DDOM). Because HDR is considered one of the important measures of the stability of a stand (Wonn \& O' Hara, 2001; Sharma et al., 2016b). The mean annual diameter increment (MDI, $\mathrm{mm} \mathrm{yr}^{-1}$ ), stand basal area $\left(\mathrm{G}, \mathrm{m}^{2} \mathrm{ha}^{-1}\right)$ and merchantable volume $\left(\mathrm{V}, \mathrm{m}^{3}\right.$ ha$\left.{ }^{1}\right)$ were also calculated. Tree-level volume equations (Petráš \& Pajtík, 1991), which were developed to estimate stem volumes for the beech trees across Slovakia, were used to estimate the standing stem volume of trees. Also, basal area and volume proportions of crop trees (GPROP and VPROP) relative to the total amounts on each subplot, were calculated. Depending on the patterns of the scatter plots of the variables of interest, various mathematical functions (Näslund's function, exponential decay function, power function, linear function) were used to model the relationship between the two variables of interest. The Näslund's function (Näslund, 1936) was used to model the relationships between DBH and stand age, height and $\mathrm{DBH}$, and crown width and stand age. A simple linear function was used to model the crown width-DBH relationship. An exponential decay function was used to model the relationships between the numbers of trees per hectare and stand age, and HDR and stand age. Similarly, a simple power function (Huxley \&
Teissier, 1936) was used to model the relationships between stand basal area and stand age, basal area proportion and stand age, stand volume and stand age, volume proportion and stand age, and mean diameter increment and stand age. Among various forms of the functions evaluated, we chose only four above-mentioned functions, because each of them provided the largest coefficient of determination $\left(\mathrm{R}^{2}\right)$. The objectives of fitting those functions to the data were to evaluate the influences of different thinning methods on the modelled relationships of variables of interest. We used the Microsoft Excel and the QC Expert software (version 3) to fit the regression functions. The $\mathrm{R}^{2}$ and $5 \%$ level of significance were used to evaluate the fitted functions.

In order to show the relationship among the various tree and stand-wise characteristics, we performed the principle component analysis (PCA) in the Canoco 5 programme (Microcomputer Power). Data were log-transformed, centered, and standardized before their analyses. The results of the PCA were visualized in the form of an ordination diagram. Differences in the subplots among thinning methods were tested by one-way analysis of variance (ANOVA), and consequently by post-hoc Tukey's HSD tests in Statistica 13 software (StatSoft). Variances were shown by standard deviation $( \pm \mathrm{SD})$.

\section{Results}

\section{Interactions between thinning types and stand characteristics}

Different thinning types showed significant positive influences on the growth and development of

Table 2. Summary of stand and tree characteristics according to thinning types for the last measurements on the plots (2012-2016). Potential differences among plots with three thinning types were tested by one-way ANOVA and posthoc Tukey HSD tests, significant difference $(p<0.05)$ among types of thinning are indicated in bold

\begin{tabular}{|c|c|c|c|}
\hline \multirow{2}{*}{ Characteristics } & \multicolumn{3}{|c|}{ Thinning type [mean ( \pm standard deviation)] } \\
\hline & No thinning $(0)$ & Low thinning (1) & Crown thinning (2) \\
\hline diameter at breast height $(\mathrm{DBH}, \mathrm{cm})$ & $37.7( \pm 9.7)$ & $41.2( \pm 10.8)$ & $44.3( \pm 11.7)$ \\
\hline height $(\mathrm{H}, \mathrm{m})$ & $32.4( \pm 6.4)$ & $34.1( \pm 6.6)$ & $33.1( \pm 6.1)$ \\
\hline height to crown base (HCB, m) & $17.1( \pm 3.8)$ & $17.6( \pm 4.1)$ & $16.6( \pm 3.5)$ \\
\hline crown width $(\mathrm{CW}, \mathrm{cm})$ & $628( \pm 156)$ & $707( \pm 151)$ & $836( \pm 214)$ \\
\hline dominant height (HDOM, m) & $34.5( \pm 2.5)$ & $36.2( \pm 2.9)$ & $35.6( \pm 2.4)$ \\
\hline dominant DBH (DDOM, cm) & $48.4( \pm 5.2)$ & $53.2( \pm 6.3)$ & $55.1( \pm 4.5)$ \\
\hline ratio of HDOM to DDOM (HDR, $\mathrm{m} \mathrm{cm}^{-1}$ ) & $0.88( \pm 0.11)$ & $0.84( \pm 0.11)$ & $0.76( \pm 0.09)$ \\
\hline stem volume per subplot $\left(\mathrm{v}, \mathrm{m}^{3}\right.$ tree $\left.^{-1}\right)$ & $1.04( \pm 0.43)$ & $2.01( \pm 0.54)$ & $1.18( \pm 0.48)$ \\
\hline number of stem per hectare $\left(\mathrm{N}, \mathrm{ha}^{-1}\right)$ & $770( \pm 236)$ & $375( \pm 95)$ & $522( \pm 122)$ \\
\hline stand basal area $\left(\mathrm{G}, \mathrm{m}^{2} \mathrm{ha}^{-1}\right)$ & $46.8( \pm 1.4)$ & $41.5( \pm 4.6)$ & $36.9( \pm 3.1)$ \\
\hline G proportion of crop trees (GPROP, \%) & $18.7( \pm 7.0)$ & $29.3( \pm 11.1)$ & $56.8( \pm 9.7)$ \\
\hline stand volume $\left(\mathrm{V}, \mathrm{m}^{3} \mathrm{ha}^{-1}\right)$ & $706( \pm 70)$ & $705( \pm 54)$ & $561( \pm 37)$ \\
\hline V proportion of crop trees (VPROP, \%) & $22.2( \pm 9.9)$ & $36.8( \pm 13.7)$ & $62.7( \pm 11.9)$ \\
\hline diameter increment (MDI, $\mathrm{mm} \mathrm{yr}^{-1}$ ) & $3.64( \pm 0.60)$ & $3.28( \pm 0.87)$ & $4.38( \pm 1.00)$ \\
\hline total volume production (TVP, $\mathrm{m}^{3} \mathrm{ha}^{-1}$ ) & $845( \pm 126)$ & $934( \pm 88)$ & $888( \pm 64)$ \\
\hline
\end{tabular}


beech stands $(\mathrm{p}<0.001-0.05)$. Thinning types had significant effects (tested LTRPs at the last measurement $)$ on the crown width $\left(\mathrm{F}_{(2,18)}=8.61, \mathrm{p}<0.01\right)$, slenderness coefficient $\left(\mathrm{F}_{(2,18)}=11.88, \mathrm{p}<0.001\right)$, stem volume $\left(\mathrm{F}_{(2,18)}=13.62, \mathrm{p}<0.001\right)$, tree density $\left(\mathrm{F}_{(2,18)}=9.01, \mathrm{p}<0.01\right)$, basal area $\left(\mathrm{F}_{(2,18)}=13.25\right.$, $\mathrm{p}<0.001)$, stand volume $\left(\mathrm{F}_{(2,18)}=6.87, \mathrm{p}<0.01\right)$, diameter increment $\left(\mathrm{F}_{(2.18}=3.92, \mathrm{p}<0.05\right)$ and proportion of crop trees (GPROP: $\mathrm{F}_{(2,18)}=30.49, \mathrm{p}<0.001$; VPROP: $\left.\mathrm{F}_{(2,18)}=20.67, \mathrm{p}<0.001\right)$. Crown width, GPROP, VPROP and diameter increment reached their largest values in the stands managed by crown thinning, and the lowest slenderness coefficient was observed for this thinning type. Stands managed by low thinning showed the highest stem volume, while the highest stand density and stand basal area occurred in the stands without thinning (Table 2).

Results of the PCA are presented in Fig. 2. The first ordination axis explained $53.8 \%$, first two $71.8 \%$, and first four axes together explained $88.7 \%$ of variability in the data. The $\mathrm{x}$-axis represents the number of trees and altitude together with DBH, DDOM, HDOM and total volume production. The y-axis represents stand volume together with VPROP and GPROP. Total volume production, stem volume, height to crown base, crown length, DBH and height were positively correlated with each other, while these variables were

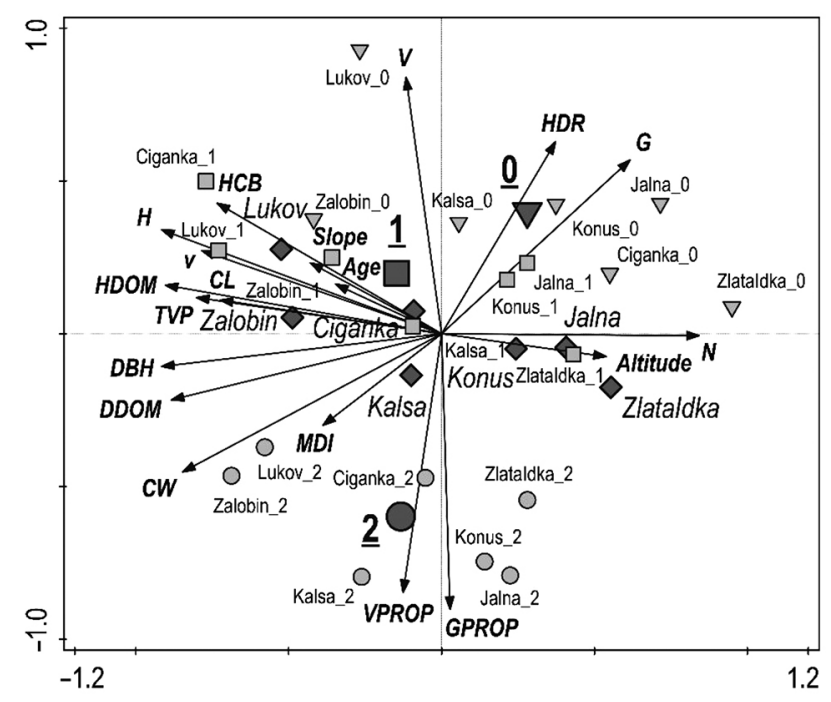

Fig. 2. Ordination diagram showing relationships among tree characteristics ( $v$ stem volume, $H$ height, HDOM dominant height, $D B H$ diameter at breast height, $D D O M$ dominant breast diameter, $C W$ crown width, $C L$ crown length, $H C B$ height to crown base, $H D R$ height to breast diameter ratio) and stand characteristics (Age mean stand age, $V$ stand volume, $G$ basal area, $N$ number of trees, TVP total volume production, VPROP volume proportion of crop trees, GPROP basal area proportion of crop trees) for the last measurements on plots (2012-2016), plot parameter (Altitude, Slope), and thinning types ( 0 no thinning, 1 low thinning, 2 crown thinning); Codes: $\bullet, \nabla$, indicate thinning type (with locality); indicates locality negatively correlated with the number of trees and altitude. Stand basal area was positively correlated with the slenderness coefficient, while these variables were negatively correlated with crown width and mean diameter increment. The VPROP and GPROP were negatively correlated with total stand volume, while they were independent from other variables, but strongly influenced by thinning types. The contributions of slope of terrain and stand age were relatively small. Thinning had significant influences on the growth and development of crop trees. Thinning types differed from one another; the crown-thinned stands with higher proportion of crop trees, crown width, diameter increment, and DBH occupied the upper part of the diagram while stands with low thinning and control stands were characterized by higher stand volume, slenderness coefficient and stand basal area and occur in the lower part of Fig. 2. Generally, thinning had positive influences on the proportion of crop trees, slenderness coefficient, crown width, diameter increment, DBH and DDOM, and negative influences on stand volume and stand basal area. Figure 2 also shows that growth of trees (especially HDOM, height, total volume production and number of trees) was substantially influenced by locality.

\section{Growth of diameter, height and crown width}

We evaluated the relationships of DBH with stand age, height with DBH, crown width with stand age, and crown width with DBH through the graphical display and fitting of the mathematical functions (Fig. 3). Diameter, height, and crown width increased with increasing stand age of beech stands irrespective of the application of thinning type. The relationship between $\mathrm{DBH}$ and stand age had the highest $\mathrm{R}^{2}$ in the stands managed by low thinning $\left(\mathrm{R}^{2}=0.78\right)$ and the lowest in the stands managed by control $\left(\mathrm{R}^{2}\right.$ $=0.69$ ) (Table 3 ). On the other hand, fitted curves for the stands managed by both crown thinning and low thinning were identical, for example, at stand age of 100 years, fitted curves showed that DBH in the stands managed by control, crown thinning and low thinning types was $38.6 \mathrm{~cm}, 44.3 \mathrm{~cm}$ and 44.3 $\mathrm{cm}$, respectively (Fig. $3 \mathrm{a}$ ). The height curves against DBH followed a practically identical course for stands managed by control and low thinning (Fig. 3b) and height values for these thinning types were larger for all trees with DBH larger than $20 \mathrm{~cm}$ in the stands managed by crown thinning. However, $\mathrm{R}^{2}$ for the stands managed by crown thinning was slightly higher $\left(\mathrm{R}^{2}=0.82\right)$ relative to that for the stands managed by control $\left(\mathrm{R}^{2}=0.81\right)$ and low thinning $\left(\mathrm{R}^{2}=\right.$ 0.79). Crown width increased with increasing stand age (Fig. 1c) and DBH (Fig. 3d). The function fitted 

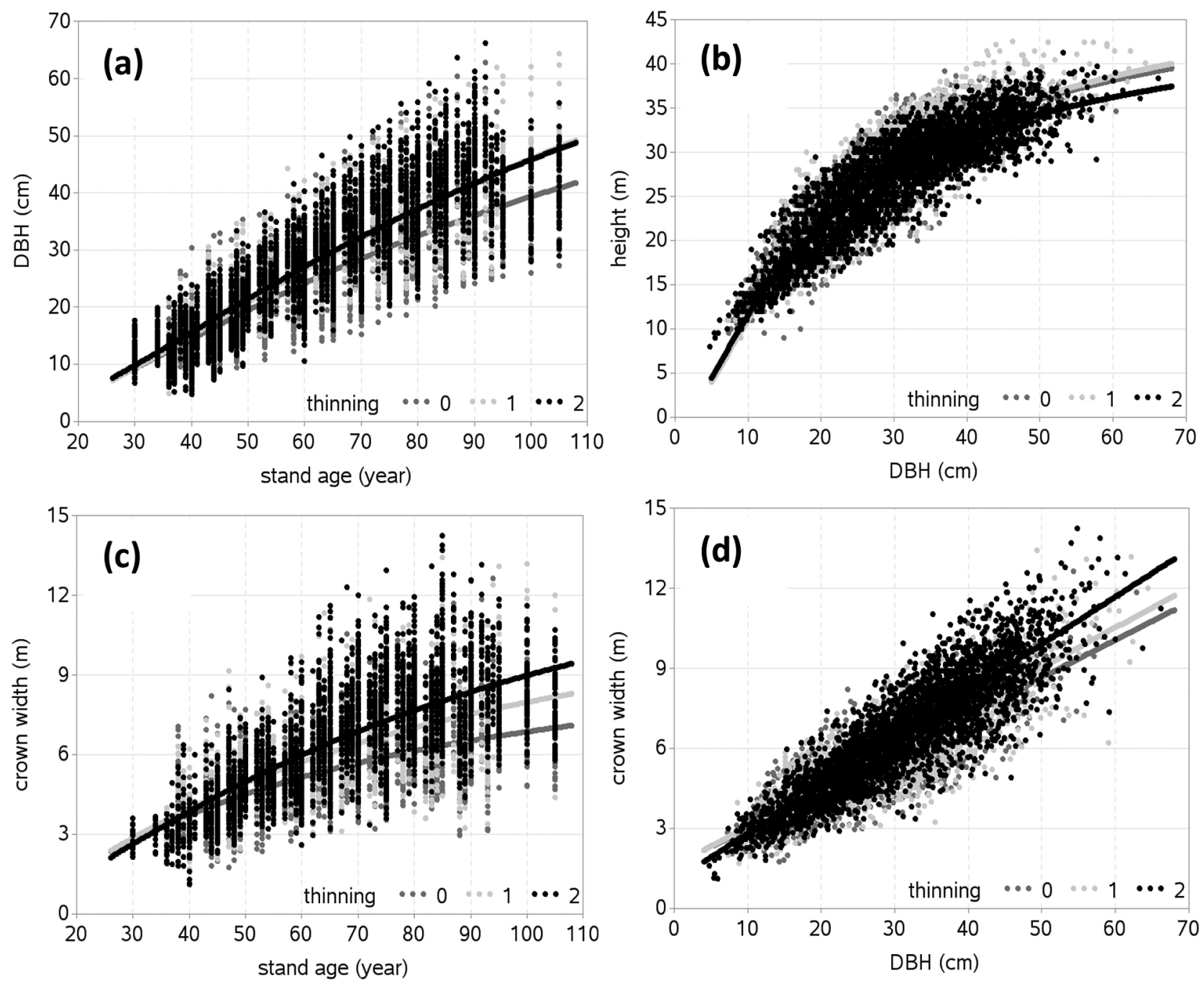

Fig. 3. Development patterns of diameter at breast height, total height, and crown width of crop trees in seven thinning experiments; Fitted curves overlaid on the observed data were produced with the corresponding functions presented in Table 3 (thinning 0: control; 1: low thinning; 2: crown thinning)

Table 3. Functions fitted to data from variables of interest [DBH: diameter at breast height $(\mathrm{cm})$; $\mathrm{H}$ : total height (m); CW: crown width (m); N: number of trees $\left(h^{-1}\right)$; G: stand basal area $\left(\mathrm{m}^{2} \mathrm{ha}^{-1}\right)$; A: stand age (year); GPROP: basal area proportion of a crop trees relative to G; V: merchantable volume $\left(\mathrm{m}^{3} \mathrm{ha}^{-1}\right)$; VPROP: merchantable volume proportion of crop trees relative to V; HDOM: dominant height (m); DDOM: DBH of dominant trees (cm); MDI: mean diameter increment $\left(\mathrm{mm} \mathrm{yr}^{-1}\right)$; HDR: ratio of $\operatorname{HDOM}$ to DDOM $\left.\left(\mathrm{m} \mathrm{cm}^{-1}\right)\right]$

\begin{tabular}{|c|c|c|c|c|c|c|}
\hline \multirow{3}{*}{$\begin{array}{l}\text { Variables } \\
\text { relationship }\end{array}$} & \multicolumn{6}{|c|}{ Thinning type } \\
\hline & \multicolumn{2}{|l|}{ No thinning $(0)$} & \multicolumn{2}{|l|}{ Low thinning (1) } & \multicolumn{2}{|l|}{ Crown thinning (2) } \\
\hline & Function & $\mathrm{R}^{2}$ & Function & $\mathrm{R}^{2}$ & Function & $\mathrm{R}^{2}$ \\
\hline DBH-age & $D=[A /(7.782+0.216 \mathrm{~A})]^{3}$ & 0.69 & $D=[A /(8.394+0 .+0.1956 \mathrm{~A})]^{3}$ & 0.78 & $D=[A /(8.031+0 .+0.199 \mathrm{~A})]^{3}$ & 0.76 \\
\hline Height-DBH & $H=[D /(1.733+0.268 \mathrm{D})]^{3}$ & 0.81 & $H=[D /(1.842+0.265 \mathrm{D})]^{3}$ & 0.79 & $H=[\mathrm{D} /(1.683+0.274 \mathrm{D})]^{3}$ & 0.82 \\
\hline CW-age & $C W=[A /(7.93+0.446 \mathrm{~A})]^{3}$ & 0.36 & $C W=[A /(8.76+0.412 \mathrm{~A})]^{3}$ & 0.42 & $C W=[A /(10.45+0.376 \mathrm{~A})]^{3}$ & 0.54 \\
\hline CW-DBH & $C W=1.607+0.141 D$ & 0.68 & $C W=1.588+0.149 D$ & 0.69 & $C W=1.031+0.177 D$ & 0.78 \\
\hline $\mathrm{N}$-age & $N=1448.8 \exp (-0.04 A)$ & 0.51 & $N=1168.5 \exp (0.0337 A)$ & 0.51 & $N=595.96 \exp (-0.02 A)$ & 0.47 \\
\hline G-age & $G=0.187 A^{0.849}$ & 0.21 & $G=0.172 A^{0.939}$ & 0.42 & $G=0.033 A^{1.398}$ & 0.57 \\
\hline GPROP-age & $G P R O P=5.91 A^{0.258}$ & 0.03 & $G P R O P=15.812 A^{0.152}$ & 0.02 & $G P R O P=0.705 A^{0.9672}$ & 0.55 \\
\hline V-age & $V=0.063 A^{1.719}$ & 0.43 & $V=0.0626 A^{1.802}$ & 0.74 & $V=0.0458 A^{1.942}$ & 0.66 \\
\hline VPROP-age & $V P R O P=15.07 A^{0.65}$ & 0.01 & $V P R O P=20.92 A^{0.091}$ & 0.01 & $V P R O P=1.277 A^{0.854}$ & 0.50 \\
\hline HDOM-DDOM & $H_{D}=\left[D_{D} /\left(2.223+0.251 \mathrm{D}_{\mathrm{D}}\right)\right]^{3}$ & 0.95 & $H_{D}=\left[D_{D} /\left(2.22+0.249 \mathrm{D}_{\mathrm{D}}\right)\right]^{3}$ & 0.91 & $H_{D}=\left[D_{D} /\left(1.83+0.27 \mathrm{D}_{\mathrm{D}}\right)\right]^{3}$ & 0.89 \\
\hline MDI-age & $M D I=13.583 A^{-0.2887}$ & 0.09 & $M D I=55.409 A^{-0.603}$ & 0.35 & $M D I=16.217 A^{-0.264}$ & 0.08 \\
\hline HDR-age & $H D R=172.44 \exp \left(-0.07 A^{0.5}\right)$ & 0.46 & $H D R=156.32 \exp \left(-0.06 A^{0.5}\right)$ & 0.44 & $H D R=205.32 \exp \left(-0.104 A^{0.5}\right)$ & 0.47 \\
\hline
\end{tabular}


to crown width against stand age showed the largest $\mathrm{R}^{2}$ for the stands managed by crown thinning $\left(\mathrm{R}^{2}=\right.$ $0.54)$ and the lowest for control stands $\left(\mathrm{R}^{2}=0.36\right)$. After the age of 40 years, the average crown width for each thinning type was significantly different with the largest crown width for stands managed by crown thinning and the lowest for control stands. Similarly, a function fitted to crown width against DBH resulted in the largest $\mathrm{R}^{2}$ for crown thinning $\left(\mathrm{R}^{2}=0.78\right)$ and the lowest for control $\left(\mathrm{R}^{2}=0.68\right)$. These results also corresponded to the highest averaged DBH of crop trees for crown thinning (Fig. 3a).
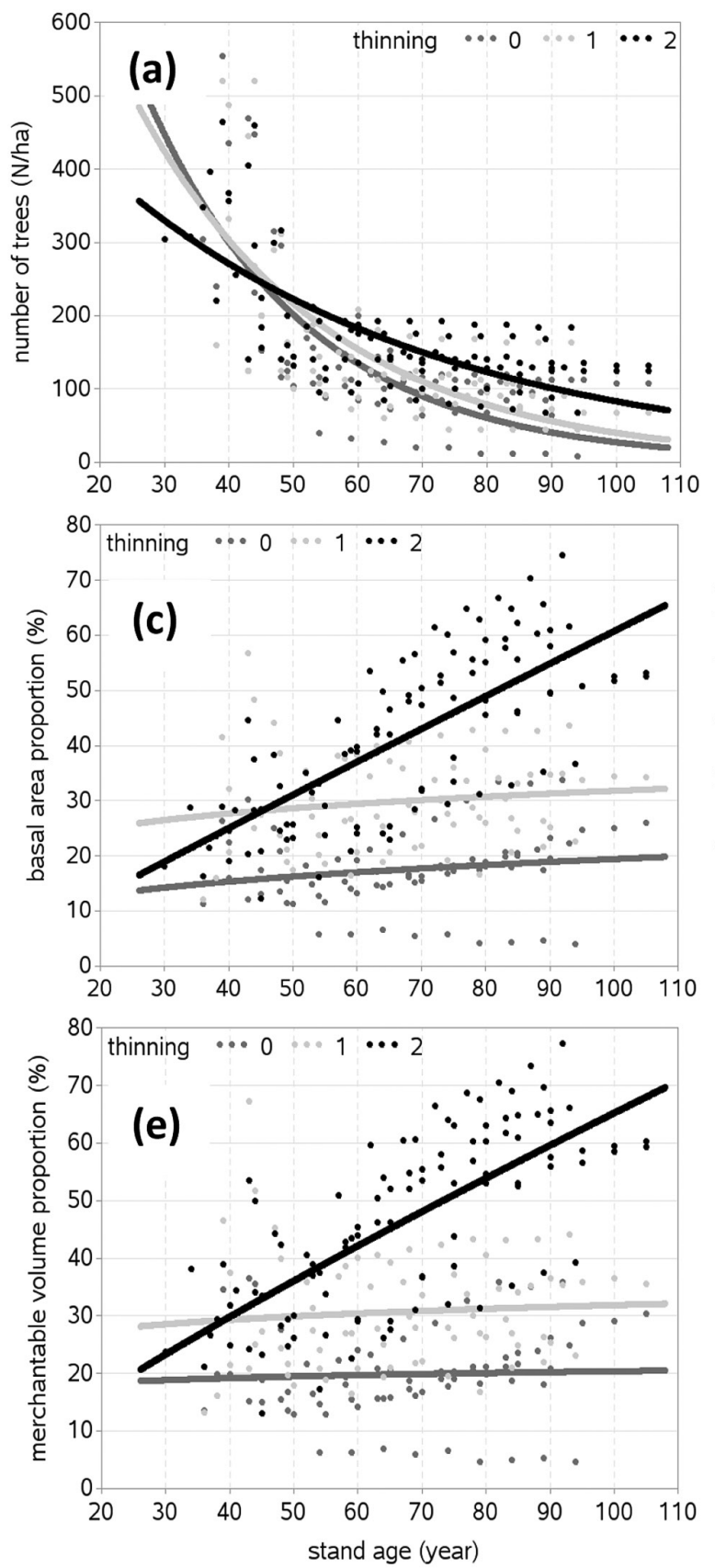

\section{Number of crop trees, basal area and merchantable volume}

The exponential decay function fitted to the number of crop trees against stand age accounted for the highest proportion of variation for both low thinning and control $\left(\mathrm{R}^{2}=0.51\right)$ and accounted for slightly less variation for this relationship for crown thinning $\left(\mathrm{R}^{2}=0.47\right)$ (Fig. 4a, Table 3). However, this function also predicted that the highest numbers of crop trees were present in the stands managed by crown thinning, ranging from 197 to 99 trees $\mathrm{ha}^{-1}$ at stand
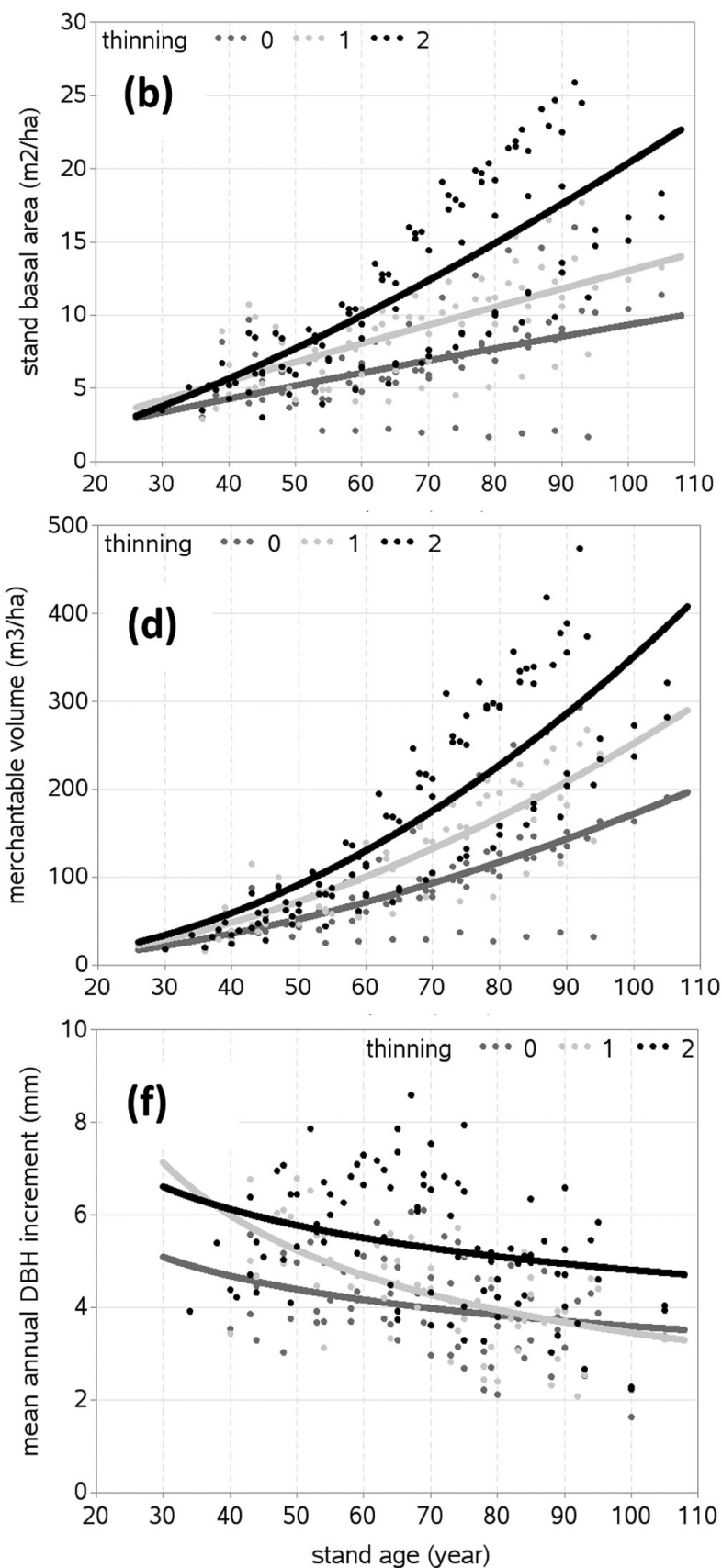

Fig. 4. Stand-and tree-level characteristics against stand age in seven thinning experiments; Fitted curves overlaid on the observed data were produced with the corresponding functions presented in Table 3 (thinning 0: control; 1: low thinning; 2: crown thinning) 
ages of 50 to 105 years. A smaller number of crop trees were predicted for the same range of stand ages for low thinning and control (179 to 59 trees and 57 to 44 trees ha ${ }^{-1}$, respectively). The proportion of number of crop trees relative to the total for control stands was $73 \%$ followed by low thinning $(68 \%)$ and crown thinning $(55 \%)$. Both stand basal area and merchantable volume of crop trees (in both total and proportion) for stands managed by crown thinning were significantly higher than for stands that had the other two management practices (Fig. 4b, c, d, e). The highest proportion was found in the stands managed by crown thinning, and the lowest proportion in the controlled stands. The regression curve showed that the proportion of crop trees in the stands managed by crown thinning was $66 \%$ of the merchantable volume at the stand age of 100 years, and while on the stands managed by low thinning and control, the proportion was only $32 \%$ and $21 \%$, respectively. The highest mean annual diameter increment occurred on the subplots managed by crown thinning (Fig. 4a). Surprisingly, for stand ages over 90 years, the mean annual diameter increment for the stands managed by low thinning was actually lower than for the control stands. The function fitted the increment data relatively poorly, describing only $35 \%, 9 \%$ and $8 \%$ variations for the stands managed by low thinning, control, and crown thinning, respectively (Table 3 ).

\section{Stand top height and slenderness coefficient}

The function fitted to the HDOM against DDOM accounted for the largest variation for stands managed by control $\left(\mathrm{R}^{2}=0.95\right)$, and the smallest variation for the stands managed by crown thinning $\left(\mathrm{R}^{2}\right.$
$=0.89$ ). After DDOM of $25 \mathrm{~cm}$, the stands managed by low thinning and control had larger HDOM, but at smaller DDOM, the stands managed by crown thinning had a larger HDOM (Fig. 5a). The curves of the function fitted to HDR (slenderness coefficient) against stand age showed decreasing HDR with increasing stand age in general, but HDR increased more rapidly for stands managed by crown thinning (Fig. 5b). This suggests that stands managed by crown thinning would be more stable to external forces than stands managed with low thinning and control. The most vulnerable stands to wind throw could be those managed by low thinning.

\section{Discussion}

In this article, we have presented the results from three different thinning regimes: crown thinning, low thinning and no thinning, that have been applied for more than 50 years in monospecific beech stands across Slovakia. Like other studies (Boncina et al., 2007; Hein et al., 2007), we also found that different thinning regimes produced changes with different magnitudes in the growth and development of crop trees (Fig. 2-5). A decreasing number of crop trees with advancing age (Fig. 4a) corresponds to the results from other studies conducted in beech stands elsewhere (Leibundgut, 1982; Štefančík et al., 1996; Boncina et al., 2007). The proportion of the numbers of crop trees relative to total trees in the stands substantially decreased with increasing thinning intensity, i.e. from control to crown thinning. This may firstly be due to higher number of crop trees selected in the initial measurements in order to reserve them, especially in the younger stands, and secondly, existence of a wide range of stand ages (30-60 years) at

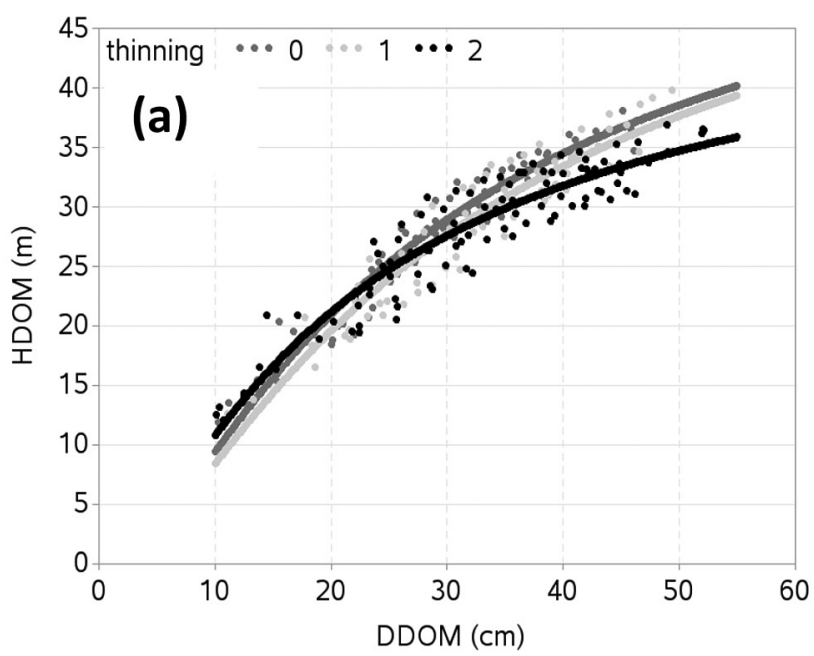

Fig. 5. Dominant height against stand age, ratio of dominant height to dominant diameter against stand age in seven thinning experiments; Fitted curves overlaid on the observed data were produced with the corresponding functions presented in Table 3 (thinning 0: control; 1: low thinning; 2: crown thinning) 
the time of selection of crop trees. Stand age could be considered as one of the most important characteristics that significantly influences the growth and development of crop trees after they are selected. A range of stand ages were found to be suitable for crop tree development, for example, selection of crop trees in beech stands could be made between 30 and 40 years (Štefančík, 1984; Spellmann \& Nagel, 1996; Guericke, 2002). However, other studies also found 60 years or even more as the most appropriate stand ages for crop tree selection (Klädtke, 1997; Štefančík, 2013). The analyses of crop trees after 45 years of systematic interventions by crown thinning confirmed a decreased number of the best quality trees, especially for the stands managed by low thinning or control.

Our results showed that the highest number of crop trees was in the stands managed by crown thinning and the lowest number in the control stands after stand age of 45 years (Fig. 4a). For example, the numbers of crop trees at age of 105 years in the stands managed by crop thinning, low thinning, and no thinning were 99, 59, 48, respectively. However, some other studies (e.g. Boncina et al., 2007) found higher numbers of crop trees in stands managed by shelter-wood cutting (176 trees ha ${ }^{-1}$ ) and heavy thinning (258 trees $\mathrm{ha}^{-1}$ ). The average distances between crop trees found from these thinnings were $5.2 \mathrm{~m}$ and $5.0 \mathrm{~m}$, respectively. We found longer distances than this, i.e. $15.2 \mathrm{~m}$ (control), $9.7 \mathrm{~m}$ (crown thinning) and $11.8 \mathrm{~m}$ (low thinning) in our stands. It would be difficult to recommend the most appropriate distance, because other factors also influence the growth and development of crop trees. Spellman \& Nagel (1996) recommended $6.5 \mathrm{~m}$, but Venet (1968) and Armand \& Ningre (2003) suggested spacing for the final crop with a rotation of about 120 years. Spellmann \& Nagel (1996) and Guericke (2002) pointed out a high number of crop trees ha ${ }^{-1}$, representing 250 and 100-300 crop trees that were selected and marked, respectively. Later, because of development of the crown surface area, a decreased number of crop trees ha ${ }^{-1}$ from 200 to 80 with advancing age, was registered. Kurt (1982) presented 80-120 crop trees for beech with the desired characteristics in relation to $\mathrm{DBH}$ as shown by yield tables. Based on the study of 20 beech stands in Switzerland, Leibundgut (1982) recommended 140-crop trees $\mathrm{ha}^{-1}$ at the top height of $35 \mathrm{~m}$. The suggested range of the number of crop trees $\mathrm{ha}^{-1}$ is relatively low (50-100 trees) in France (Bouchon et al., 1989; Armand \& Ningre, 2003). Klädtke (2002) suggested that more than 100 crop trees should not be selected, because the probability of red heart formation would be higher due to the longer production period. Because of this, Klädtke (2002) suggested a limit of the mean diameter of $60 \mathrm{~cm}$ and stand age of 120 years in order to avoid red heart formation. Dhôte (1997) recommended a rotation length of 15-20 years by application of intensive thinning, which might reduce the red heart formation. Boncina et al. (2007) expected about 150 -crop trees $\mathrm{ha}^{-1}$ in the final crop, which is also in line with the recommendation made by Schütz (1996).

Like other studies (Bastien, 1995; Klädtke, 1997), we also found positive influences on diameter increment due to early and heavy thinning. The mean annual increment increased with increasing thinning intensity (Fig. 4f). Klädtke (1997) found that thinning resulted in a significantly increased rate of diameter growth of crop trees in beech stands. However, compared to our results, probability of getting larger diameter trees would be higher in the thinning data analyzed by Klädtke (1997). Both basal area $\left(\mathrm{m}^{2} \mathrm{ha}^{-1}\right)$ and volume $\left(\mathrm{m}^{3} \mathrm{ha}^{-1}\right)$ of crop trees vary with thinning types (Fig. 4b, 4d), where the highest and lowest increments were produced in the stands managed by crown thinning and control, respectively. This is due to existence of the largest number of crop trees in the stands managed by crown thinning and the smallest numbers of crop trees in the stands managed by control. Lüpke (1986) analyzed beech at stand ages of $52,78,101$ and 122 years, managed by thinning from above, and found basal areas of 21 to $24 \mathrm{~m}^{2} \mathrm{ha}^{-1}$. However, our results of crown thinning showed basal area of $20 \mathrm{~m}^{2} \mathrm{ha}^{-1}$ at stand age of 100 years (Fig 4b), and simulation results showed basal area of $25.6 \mathrm{~m}^{2} \mathrm{ha}^{-1}$ at stand age of 122 years. Bobinac (2004) compared the growth in 2002 to that in 1985 before thinning and found lower increments of basal area (198\%) and volume (278\%), for the control stands compared to those for the thinned stands (basal area increment $256-263 \%$ and volume increment $379-399 \%$ during 17 years). The proportions of basal area and volume of crop trees relative to the total amounts in a stand also increased with increasing thinning intensity (Fig. 4c, 4e). The largest proportion was found in the stands managed by crown thinning and the lowest in the control stands. The current average volume proportion $(66 \%)$ in the stands managed by crown thinning at stand age of 105 years could potentially be increased to $80-85 \%$ at a rotation of 120 years. The largest rate of DBH increment of crop trees was also found in the stands managed by crown thinning (Fig. 4f). This may be due to crown release, but crowns of crop trees were not purposely liberated through low thinning and control. They were marked, registered and re-assessed in the subsequent measurements. If one of these criteria (best stem quality, diameter and height dimensions and regular spacing - Štefančík 1984) was not found on crop trees in subsequent measurements, their registration had to be cancelled. Other criteria such as age, height and diameter may also be taken into consideration for assessing growth 
of the selected crop trees, and they need to be compared against site-specific growth norms (Abetz \& Klädtke, 2002). Growth norms describe optimal growth of crop trees towards a specified production goal, which could be modified by forest owners based on their requirements.

Thinning, irrespective of its intensity, significantly influences the static stability of the beech stands, which is commonly assessed by height-diameter ratio (HDR, also called slenderness coefficient). Generally, smaller HDR indicates lower centers of gravity of trees with longer crown lengths, but also higher stability than trees with larger HDR (Opio et al., 2000; Bošela et al., 2014; Sharma et al., 2016b). Crown thinning resulted in smaller values of HDR than the other two management regimes for stand ages over 50 years (Fig. 5b). This is because the regular spacing of crop trees produced by crown thinning may create an appropriate stand skeleton. The stands managed by crown thinning would be attributed to regular and medium-sized crowns of crop trees. Guericke (2002) analyzed data from four thinning experiments in Germany, and found that medium crowns were more productive than the trees with extremely large crowns. Therefore, higher numbers of crop trees would lead to better spatial distribution and higher stand stability. A number of larger trees were removed as competitors from the stands managed by crown thinning, especially by the first three interventions. After 10-20 years of interventions, diameter and height growth of crop trees accelerated due to the liberation of crowns. However, tree crowns in the stands managed by low thinning and control still remained crowded at that time. This was also confirmed by the results shown from the modelled relationships of crown width against stand age and crown width against DBH (Fig. 3c, 3d). In order to secure a strong stand skeleton, which is only possible in stands having HDR $<0.8$, crown thinning can be considered as the best management intervention (Fig. 5b). Rymer-Dudzińska \& Tomusiak (2000) reported that HDR of beech stands depended mainly on the mean $\mathrm{DBH}$ and stand age, but the former variable was much stronger $(r=-0.797)$ than the latter $(r=-0.603)$. However, their values of HDR were higher than those of our study (Table 3), indicating that our beech stands could be more stable than those studied by Rymer-Dudzińska \& Tomusiak (2000).

Results from the observed period show that there has been a shift in height structure of trees due to thinning regimes and natural development. On LTRPs with heavy thinning from below, the proportion of dominant trees increased, while minor changes in stand structure occurred after application of free-crown thinning. These results are consistent with those of the thinning experiments established in the past (Assmann, 1961; Štefančík, 1972). The PCA (Fig. 2) shows that stands without intervention have higher volume production and number of trees than managed stands, regardless of thinning methods applied. This fact, together with higher mean DBH on thinning plots, is evidenced by research in Slovakia (Štefančík \& Bolvanský, 2011) and Germany (Diaconu et al., 2015). In contrast, Bobinac (2004) found the lowest volumes on control as compared to the managed sample plots. Similar results were also observed from beech forests in Germany (Pretzsch, 2005), where three types of thinning from below (weak, medium, strong) were compared in stands at the age of 100 years. There, total stand volume was the highest after application of heavy thinning. In our study, the PCA also showed that the production quality of beech stands was significantly influenced by thinning type, as in other studies (i.e. it is important to start thinning at early ages - 20-30 years; Mlinšek \& Bakker, 1990; Jullien et al., 2013; Štefančík \& Bošela, 2014; Štefančík, 2015). A high quality of wood production in beech stands may be reached due to the application of strong thinning intervention (cf. Utschig \& Küsters, 2003; Hein et al., 2007; Poljanec \& Kadunc, 2013). Specifically, in terms of value production, Štefančík et al. (2018) in the same study sites, found that the highest volume of the best quality of stems occurred in forests where free-crown thinning (57-85\%) was applied, while the lowest $(22-56 \%)$ was in the control stands. The proportion of the two best commercial quality assortments was the highest in the stands managed by low thinning (21-29\%) and the lowest in the stands without any intervention (7-19\%).

From an ecological point of view, the applied methods of thinning of beech stands contribute to increased ecological stability, vitality, regeneration capacity and biodiversity; in particular by interfering at all stand levels (Masarovicová \& Štefančík, 1990). Thinning also contributes to the ultimate role in mitigating the impacts of climate warming. Forests that are more vertically diversified include less climate-sensitive components (e.g. suppressed trees sheltered by canopy) that decrease the intensity of climate-growth response (Bošela et al., 2016). The most suitable height and diameter differentiation according to Füldner (1995) was observed on the sample plots managed by free-crown thinning, where interventions were realized in the whole vertical profile, in contrast to the control stands and the stands managed by low thinning (Štefančík, 2015). Additionally, the resistance of beech is higher in mixed forests in terms of climate warming and drying (Bošela et al., 2016). Long-term studies (Pretzsch et al., 2014; Bošela et al., 2016) also show an increase of a total yield production since the 1960s in the Central Europe, ranging from $5 \%$ to $40 \%$, particularly in 
less productive sites. Moreover, while an increase of the mean annual basal area increment continues in the unmanaged stands, it has recently slowed down in the stands managed by free-crown thinning and even it started decreasing in the stands where low thinning was applied (Bošela et al., 2016). Thus, the competitive capacity of beech might be reduced under the expected future climate conditions. Silvicultural practitioners must be aware of the potential risks today, which a changing climate may impose on sustainable forest management (Geßler et al., 2007).

\section{Conclusion}

The study carried out for more than 50 years on crop trees under different management regimes in beech stands showed positive influences on the growth and development of the trees due to longterm thinning. Thinning (regardless of intensity and method) focused predominantly on development of crop trees resulted in more favorable results than in the stands left to self-development. However, in the management of beech stands originated by natural regeneration, not only the methods of thinning are important, but also the stand age at which it starts. It can be the best to start thinning up to age of 30 years, since after that, thinning loses its purpose. The method of free-crown thinning can be recommended for beech stands in order to achieve the highest number of crop trees, the largest basal area and volume increments, and most stable stands. Simultaneously, these trees could be good components of higher stand site quality. We could assume that thinning methods focused mainly on individual trees may lead to the production of the most valuable assortments. At the same time, this approach seems to provide a useful perspective on the restoration of age class structure of forest stands for the selection system. Its conception includes many elements of closeto-nature silviculture, especially diameter and height differentiation of the forest stands.

\section{Acknowledgement}

The study was supported by the Slovak Research and Development Agency under Contract No. APVV-0262-11 and No. APVV-15-0032 as well as by Technology Agency of the Czech Republic (No. TA02021250 Silvicultural-ecological and economic optimum of forest stand thinning) and Faculty of Forestry and Wood Sciences, Czech University of Life Sciences in Prague (IGA No. B03/18). We thank two anonymous reviewers for their constructive comments and insightful suggestions that helped improve the article.

\section{References}

Abetz P \& Klädtke J (2002) Die z-baum-kontrollmethode. Forstwissenschaftliches Centralblatt 121: 73-82.

Abetz P \& Ohnemus K (1999) Überprüfung von z-baum-Normen für buche anhand einer versuchsfläche. Allgemeine Forst und Jagd Zeitung 170: 157-165.

Altherr E (1981) Erfahrungen bei der anwendung quantifizierter durchforstungshilfen in buchen beständen. Allgemeine Forstzeitschrift 36: 552554.

Armand G \& Ningre F (2003) Produire du hêtre autrement sur le mode régulier. Forêt- entreprise 154: 19-22.

Assmann E (1961) Waldertragskunde: organische produktion, struktur, zuwachs und ertrag von waldbeständen. BLV Verlagsgesellschaft, München, Bonn, Wien, Germany.

Barna M, Sedmák R \& Marušák R (2010) Response of European beech radial growth to shelterwood cutting. Folia Oecologica 37: 125-136.

Bastien Y (1995) L'expérience danoise d'éclaire de hêtre de totterup. Revue Forestiére Française 47: 133-136.

Bobinac M (2004) Effects of selection thinning on beech tree and stand increment on Mt. Južni Kučaj. Glasnik Šumarskog Fakulteta 90: 65-78.

Boncina A, Kadunc A \& Robic D (2007) Effects of selective thinning on growth and development of beech (Fagus sylvatica L.) forest stands in south-eastern Slovenia. Annals of Forest Science 64: 47-57.

Bošela M, Konôpka B, Šebeň V, Vladovič J \& Tobin B (2014) Modelling height to diameter ratio an opportunity to increase Norway spruce stand stability in the Western Carpathians. Lesnicky Casopis-Forestry Journal 60: 71-80.

Bošela M, Štefančík I, Petráš R \& Vacek S (2016) The effects of climate warming on the growth of European beech forests depend critically on thinning strategy and site productivity. Agricultural and Forest Meteorology 222: 21-31.

Bouchon J, Dhôte JF \& Lanier L (1989) Réaction individuelle de hêtres (Fagus sylvatica L.) d'âges divers à diverses intensités d'éclaircie. Annals Science of Forestry 46: 251-259.

Bulušek D, Vacek Z, Vacek S, Král J, Bílek L \& Králíček I (2016) Spatial pattern of relict beech (Fagus sylvatica L.) forests in the Sudetes of the Czech Republic and Poland. Journal of Forest Science 62: 293-305.

Cameron AD (2002) Importance of early selective thinning in the development of long-term stand stability and improved log quality: a review. Forestry 75: 25-35. 
Dassot M, Constant T, Ningre F \& Fournier M (2015) Impact of stand density on tree morphology and growth stresses in young beech (Fagus sylvatica L.) stands. Trees 29: 583-591.

Dhôte JF (1997) Effets des éclaircies sur le diamétre dominant dans des futaies réguliéres de hêtre ou de chêne sessile. Revue Forestiére Française 49: 557-578.

Diaconu D, Kahle HP \& Spiecker H (2015) Tree-and stand-level thinning effects on growth of european beech (Fagus sylvatica L.) on a Northeast-and a Southwest-facing slope in Southwest Germany. Forests 6: 3256-3277.

Drobyshev I, Övergaard R, Saygin I, Niklasson M, Hickler T, Karlsson M \& Sykes MT (2010) Masting behaviour and dendrochronology of European beech (Fagus sylvatica L.) in southern Sweden. Forest Ecology and Management 259: 2160-2171.

Ekö PM, Pettersson N \& Bjerregaard J (1995) Pre-commercial thinning in European beech $(\mathrm{Fa}$ gus sylvatica L.): Results from a field trial. Forest and Landscape Research 1: 207-226.

Fichtner A, Sturm K, Rickert C, Härdtle W \& Schrautzer J (2012) Competition response of European beech Fagus sylvatica L. varies with tree size and abiotic stress: minimizing anthropogenic disturbances in forests. Journal of Applied Ecology 49: 1306-1315.

Foerster W (1993) Der buchen-durchforstungsversuch. Allgemeine Forstzeitschrift 48: 268-270.

Füldner K (1995) Zur beschreibung in mischbeständen. Forstarchiv 66: 235-240.

Fürst C, Vacik H, Lorz C, Makeschin F, Podrázský V \& Janeček V (2007) Meeting the challenges of process-oriented forest management. Forest Ecology and Management 248: 1-5.

Geßler A, Keitel C, Kreuzwieser J, Matyssek R, Seiler W \& Rennenberg H (2007) Potential risks for European beech (Fagus sylvatica L.) in a changing climate. Trees 21: 1-11.

Gömöry D, Comps B, Paule L \& von Wühlisch G (2013) Allozyme and phenotypic variation in beech (Fagus sylvatica L.): are there any links? Plant Biosystems 147: 265-271.

Gömöry D \& Paule L (2011) Trade-off between height growth and spring flushing in common beech (Fagus sylvatica L.). Annals of Forest Science 68: 975-984.

Guericke M (2002) Untersuchungen zur wuchsdynamik der buche. Forst und Holz 57: 331-337.

Hansen JK, Jorgensen BB \& Stoltze P (2003) Variation of quality and predicted economic returns between European beech (Fagus sylvatica L.) provenances. Silvae Genetica 52: 185-197.

Huxley JS \& Teissier G (1936) Terminology of relative growth. Nature 137: 780-781.
Jiao-jun Z, Feng-qin L, Yutaka G, Matsuzaki T \& Yamamoto M (2003) Effects of thinning on wind damage in Pinus thunbergii plantation. Journal of Forest Research 14: 1-8.

Jullien D, Widmann R, Loup C \& Thibaut B (2013) Relationship between tree morphology and growth stress in mature European beech stands. Annals of Forest Science 70: 133-142.

Kennel R (1972) Die buchendurchforstungsversuche in Bayern von 1870 bis 1970. Forstliche Forschungsberichte München 7: 264.

Klädtke J (1997) Buchen-lichtwuchsdurchforstung. Allgemeine Forst Zeitschrift fur Waldwirtschaft und Umweltvorsorge 52: 1019-1023.

Klädtke J (2002) Growth of beeches with large crowns and consequences for silviculture. Forstarchiv 73: 211-217.

Kraft G (1884) Beiträgezur zur lehre von den durchforstungen, schlagstellungen und lichtungshieben. Klindworth, Hannover, Germany.

Králíček I, Vacek Z, Vacek S, Remeš J, Bulušek D, Král J, Štefančík I \& Putalová T (2017) Dynamics and structure of mountain autochthonous sprucebeech forests: impact of hilltop phenomenon, air pollutants and climate. Dendrobiology 77: 119137.

Kurt A (1982) Ziel, voraussage und kontrolle von nutzungen im forstbetrieb. Schweizerische Zeitschrift für Forstwesen 133: 93-114.

LeGoff N \& Ottorini JM (1993) Thinning and climate effects on growth of beech (Fagus sylvatica L.) in experimental stands. Forest Ecology and Management 62: 1-14.

Leak WB \& Solomon DS (1997) Long-term growth of crop trees after release in northern hardwoods. Northern Journal of Applied Forestry 14: 147151.

Leibundgut H (1982) Über die anzahl auslesenbäume bei der auslesedurchforstung. Schweizerische Zeitschrift für Forstwesen 133: 115-119.

Masarovicová E \& Štefančík L (1990) Some ecophysiological features in sun and shade leaves of tall beech trees. Biologia Plantarum 32: 374-387.

Mlinšek D \& Bakker A (1990) Jugendwachstum und holzqualität bei der buche. Forstwissenschaftliches Centralblatt 109: 242-248.

Näslund M (1936) Skogsforsö ksastaltens gallringsforsök i tallskog. Meddelanden fran Statens Skogsforsöksanstalt 29: 1-169.

Nykänen ML, Peltola H, Quine C, Kellomäki S \& Broadgate M (1997) Factors affecting snow damage of trees with particular reference to European conditions. Silva Fennica 31: 193-213.

Opio C, Jacob N \& Coopersmith D (2000) Height to diameter ratio as a competition index for young conifer plantations in northern British Columbia, 
Canada. Forest Ecology and Management 137: 245-252.

Oswald H (1981) Résultats principaux des places d'expérience de chêne du Centre national de Recherches forestières. Revue Forestiere Francaise 33: 65-85.

Petráš R \& Pajtík J (1991) Sústava česko-slovenských objemových tabuliek drevín. Lesnický Časopis 37: 49-56.

Pichler V, Ďurkovič J, Capuliak J \& Pichlerová M (2009) Altitudinal variability of the soil water content in natural and managed beech (Fagus sylvatica L.) forests. Polish Journal of Ecology 57: 313-319.

Piovesan G \& Adams JM (2001) Masting behaviour in beech: linking reproduction and climatic variation. Canadian Journal of Botany 79: 1039-1047.

Polge H (1981) Influence des éclaircies sur les contraintes de croissance du hêtre. Annals of Forest Science 38: 407-423.

Poljanec A \& Kadunc A (2013) Quality and timber value of European beech (Fagus sylvatica L.) trees in the Karavanke region. Croatian Journal of Forest Engineering 34: 151-165.

Pretzsch H (2005) Stand density and growth of Norway spruce (Picea abies [L.] Karst.) and European beech (Fagus sylvatica L.): evidence from long-term experimental plots. European Journal of Forest Research 124: 193-205.

Pretzsch H, Grote R, Reineking B, Rötzer T \& Seifert $S$ (2008) Models for forest ecosystem management: A European perspective. Annals of Botany 101: 1065-1087.

Pretzsch H, Biber P, Schütze G, Uhl E \& Rötzer T (2014) Forest stand growth dynamics in Central Europe have accelerated since 1870. Nature Communications 5: 4967.

Prka M \& Krpan APB (2010) Impact of tending measures on assortment structure of fellings in central Croatian beech stands. Acta Silvatica et Lignaria Hungarica: An International Journal in Forest, Wood and Environmental Sciences 6: 171-182.

Ratnam W, Rajora OP, Finkeldey R, Aravanopoulos F, Bouvet JM, Vaillancourt RE, Kanashiro M, Fady B, Tomita M \& Vinson C (2014) Genetic effects of forest management practices: Global synthesis and perspectives. Forest Ecology and Management 333: 52-65.

Remeš J, Bílek L, Novák J, Vacek Z, Vacek S, Putalová T \& Koubek L (2015) Diameter increment of beech in relation to social position of trees, climate characteristics and thinning intensity. Journal of Forest Science 61: 456-464.

Rymer-Dudzińska T \& Tomusiak R (2000) Comparison of slenderness in beech and oak stands. Sylwan 144: 45-52.
Schütz JP (1996) Bedeutung und möglichkeiten der biologischen rationalisierung im forstbetrieb. Schweizerische Zeitschrift für Forstwesen 147: 315-344.

Sharma RP, Vacek Z \& Vacek S (2016a) Individual tree crown width models for Norway spruce and European beech in Czech Republic. Forest Ecology and Management 366: 208-220.

Sharma RP, Vacek Z \& Vacek S (2016b) Modeling individual tree height to diameter ratio for Norway spruce and European beech in Czech Republic. Trees 30: 1969-1982.

Sharma RP, Vacek Z, Vacek S, Podrázský V \& Jansa V (2017a) Modelling individual tree height to crown base of Norway spruce (Picea abies (L.) Karst.) and European beech (Fagus sylvatica L.). PloS one 12: e0186394.

Sharma RP, Vacek Z \& Vacek S (2017b) Modelling tree crown-to-bole diameter ratio for Norway spruce and European beech. Silva Fennica 51: 1740.

Skovsgaard JP, Nordfjell T \& Sörensen IH (2006) Pre-commercial thinning of beech (Fagus sylvatica L.): early effects of stump height on growth and natural pruning of potential crop trees. Scandinavian Journal of Forest Research 21: 380-387.

Spellmann H \& Nagel J (1996) Zur durchforstung von fichte und buche. Allgemeine Forst und Jagdzeitung 167: 6-15.

Štefančík I (2012) Development of spruce (Picea abies [L.] Karst.) target (crop) trees in pole-stage stand with different initial spacing and tending regime. Journal of Forest Science 58: 456-464.

Štefančík I (2013) Development of target (crop) trees in beech (Fagus sylvatica L.) stand with delayed initial tending and managed by different thinning methods. Journal of Forest Science 59: 253-259.

Štefančík I (2015) Growth, structure and production of beech stands with different thinning regimes. Národné lesnícké centrum Zvolen, Zvolen, Slovak Republic.

Štefančík I \& Bolvanský M (2011) Pestovanie bukových porastov: Buk a bukové ekosystémy Slovenska (ed. by M Barna, J Kulfan \& E Bublinec E) Bratislava, Veda, Slovak Republic, pp. 431-452.

Štefančík I \& Bošela M (2014) An influence of different thinning methods on qualitative wood production of European beech (Fagus sylvatica L.) on two eutrophic sites in the Western Carpathians. Journal of Forest Science 60: 406-416.

Štefančík I, Bošela M \& Petráš R (2018) Effect of different management on quality and value production of pure beech stands in Slovakia. Central European Forestry Journal 63: 24-32.

Štefančík L (1972) Die unterschiede im durchforstungsvolumen von buchenbeständen in abhängigkeit von der höhenkurve des gesamt- und 
des ausscheidenden bestandes. Forstwissenschaftliches Centralblatt 91: 142-152.

Štefančík L (1973) Waldbauliche analyse einer freien hochdurchforstung in ungepflegten buchenstangenhölzern. Forstwissenschaftliches Centralblatt 92: 242-249.

Štefančík L (1984) Freie hochdurchforstung in ungepflegten buchenstangenhölzern. Allgemeine Forstzeitung 95: 106-110.

Štefančík L, Utschig H \& Pretzsch H (1996) Parallel observations of unmixed beech stand growth and structure on long range thinning research plots in Bavaria and Slovakia. Lesnictví-Forestry 42: 3-19.

Utschig H \& Küsters E (2003) Growth reactions of common beech (Fagus sylvatica L.) related to thinning - 130 years observation of the thinning experiment Elmstein 20. Forstwissenschaftliches Centralblatt 122: 389-409.

Utzschig H (2013) Relevance of long term experimental plots for the design of new silvicultural concepts. Allgemeine Forst und Jagdzeitung 184: 159-167.

Vacek S \& Hejcman M (2012) Natural layering, foliation, fertility and plant species composition of a Fagus sylvatica stand above the alpine timberline in the Giant (Krkonoše) Mts., Czech Republic. European Journal of Forest Research 131: 799-810.

Vacek S, Vacek Z, Podrázský V, Bílek L, Bulušek D, Štefančík I, Remeš J, Stícha V \& Ambrož R (2014a) Structural diversity of autochthonous beech forests in Broumovské Stěny National Nature Reserve, Czech Republic. Austrian Journal of Forest Science 131: 191-214.

Vacek S, Černý T, Vacek Z, Podrázský V, Mikeska M \& Králíček I (2017b) Long-term changes in vegetation and site conditions in beech and spruce forests of lower mountain ranges of Central Europe. Forest Ecology and Management 398: 75-90.

Vacek Z, Vacek S, Bílek L, Král J, Remeš J, Bulušek D \& Králíček I (2014b) Ungulate impact on natural regeneration in spruce-eeech-fir stands in Černý důl Nature Reserve in the Orlické Hory Mountains, case study from Central Sudetes. Forests 5: 2929-2946.

Vacek Z, Vacek S, Bílek L, Remeš J \& Štefančík I (2015a) Changes in horizontal structure of natural beech forests on an altitudinal gradient in the Sudetes. Dendrobiology 73: 33-45.

Vacek Z, Vacek S, Podrázský V, Bílek L, Štefančík I, Moser WK, Bulušek D, Král J, Remeš J \& Králíček I (2015b) Effect of tree layer and microsite on the variability of natural regeneration in autochthonous beech forests. Polish Journal of Ecology 63: 233-246.

Vacek Z, Bulušek D, Vacek S, Hejcmanová P, Remeš J, Bílek L \& Štefančík I (2017a) Effect of microrelief and vegetation cover on natural regeneration in European beech forests in Krkonose national parks (Czech Republic, Poland). Austrian Journal of Forest Science 134: 75-96.

van der Maaten E (2013) Thinning prolongs growth duration of European beech (Fagus sylvatica L.) across a valley in southwestern Germany. Forest Ecology and Management 306: 135-141.

Venet J (1968) Pratique de la pré-désignation des arbres de place. Revue Forestiere Française 20: 157-169.

Westergren M, Bozic G, Ferreira A \& Kraigher H (2015) Insignificant effect of management using irregular shelterwood system on the genetic diversity of European beech (Fagus sylvatica L.): A case study of managed stand and old growth forests in Slovenia. Forest Ecology and Management 335: 51-59.

Wonn HT \& O'Hara KL (2001) Height: diameter ratios and stability relationships for four northern rocky mountain tree species. Western Journal of Applied Forestry 16: 87-94.

Zeibig A, Diaci J \& Wagner S (2005) Gap disturbance patterns of a Fagus sylvatica virgin forest remnant in the mountain vegetation belt of Slovenia. Forest Snow and Landscape Research 79: 69-80. 